\title{
Submucosal 1 Invasion
}

National Cancer Institute

\section{Source}

National Cancer Institute. Submucosal 1 Invasion. NCI Thesaurus. Code C155963.

Submucosal tumor invasion into the upper third of the submucosal tissue. 